\title{
Dispatch
}

\section{The REDress Project: Casting an Indigenous Feminist Worldview on Sexual Violence Prevention and Education Programs in Ontario's Universities}

\author{
ELIZABETH BRULÉ \\ Queen's University, Canada
}

When the call for submissions to commemorate the 10-year anniversary of the death of feminist activist Jackie Kirk was released, I was struck by her legacy and the important work she had accomplished in advancing education for women and girls' in conflict and post-conflict zones (Kirk, 2009; Mango \& Kirk, 2008; 2010; Mundy \& Dryden Peterson, 2011). As an educator, scholar and community advocate, she provided in-depth analyses of the gender dynamics of education within complex geopolitical environments. Her dedication to social justice activism inspired feminist academics in the field to make a political commitment to advance women and children's rights worldwide. And yet, I was equally struck by the fact that it has been four years since the death of Tina Fontaine, a 15-year-old Anishinaabe girl from Sagkeeng First Nation in Canada, ${ }^{1}$ a country that boasts the highest number of college and university graduates among the Organisation for Economic Cooperation and Development (OECD) countries (Statistics Canada, 2017). On February 22, 2018, Tina Fontaine's alleged murderer, 56-year-old Raymond Cormier, was found not guilty.

Two years ago, Bill 132 - The Sexual Violence and Harassment Action Plan Act - was passed by the Legislative Assembly of Ontario (2016). It requires universities and colleges throughout the province to implement sexual violence prevention and education programs and policies that address sexual violence perpetrated against students enrolled in their educational institutions. Although the resulting post-secondary response has involved a plethora of activities that meet the legislative requirements, few address

\footnotetext{
${ }^{1}$ Many Indigenous peoples refer to the territory that makes up North America as Turtle Island. 
sexual violence prevention and education from an Indigenous feminist antiracist perspective. ${ }^{2}$ This, despite the fact that gender-based violence against Indigenous women, girls, transgender and two-spirit persons (MMWGT2S) presents one of the most pressing issues in Canada as documented by the Truth and Reconciliation Commission of Canada (TRC, 2015). In the past three decades, there have been more than 1,000 unresolved cases of murdered or missing Indigenous women, girls, transgender and two-spirit persons in this country (Bourgeois, 2017). ${ }^{3}$ According to the Native Women's Association of Canada (NWAC, 2009), Indigenous women are three times more likely to be killed by a stranger than non-Indigenous women, and five times more likely to be killed by someone they know.

This recent legislation and the TRC's Calls to Action (TRC, 2015) provided a perfect opportunity for York University's Indigenous students, staff and faculty, along with non-Indigenous allies, to come together to address the lack of student awareness of MMIWGT2S. As a scholar of Métis heritage and an educator in the Department of Equity Studies at the University, I was acutely aware of faculty, staff and students' lack of knowledge and the need to create an open discussion about the gendered and racialized nature of the violence that Indigenous peoples have endured since colonization. In following Linda Tuhiwai Smith's work (2012), our community did not want to replicate colonial representations of Indigenous peoples, but rather challenge these through participation, dialogue, and education. Like much of Kirk's work, our aim was to foster a collective dialogue and provide an Indigenous feminist narrative on gender-based violence (Mango \& Kirk 2008; 2010). This dispatch is about our six-month collective endeavour in $2017 / 18$ to challenge and reframe colonial representations of Missing and Murdered Indigenous Women, Girls, Transgender and Two-Sprit people through the installation of the REDress Project and its associated events at York University.

Initiated in 2010, the REDress Project is an aesthetic response to the over 1,000 unresolved cases of missing and murdered Indigenous women, girls, transgender and two-spirit persons in Canada. Originally created by Winnipeg based Métis artist, Jamie Black, the project involves the installation of red dresses throughout various venues and land-based spaces. Using donated red dresses, Black (2014) creates installation art projects that serve as a "visual reminder of those unsolved cases and those who are missing." To this end, a REDress committee was formed and led by Glendon student Kanisha Brown-Bear (Mi'kmaq) of the Indigenous Students Association at

\footnotetext{
${ }^{2}$ Few universities have addressed this issue with the exception of York and Brock University who installed a REDress Project on their campuses in 2018, as did the University of Toronto on International Women's Day, March $8^{\text {th }} 2017$.

${ }^{3}$ Bourgeois (2017, pp. 257-260) documents how these numbers are grossly underestimated due to racialized policing practices that mistakenly identify MMWGT2 deaths as accidental or due to unknown causes. See also Kubik \& Bourassa (2016) for an additional analysis of the 2014 Royal Mounted Police final report on MMIWGT2S.
} 
Glendon (ISAG), and myself, in cooperation with the Indigenous Council at York (ICY), the Aboriginal Students Association at York (ASAY), the Osgood Indigenous Students Association (OISA), and allies from both campuses. Having installed a successful REDress Project the year before on York's Glendon Campus, Kanisha Brown-Bear wanted to expand the project to include York's main Keele campus. Based on this initiative, and with our Indigenous students, staff and faculty as the co-leads, our working group consisted of 14 campus partners, ${ }^{4}$ and met regularly over a six-month period to ensure the project's success. With extensive financial, administrative and logistical support from the university, dress donations from the wider community - including the Department of Gender Studies at the University of Toronto - and the help of over 50 student ally volunteers, we were able to collect, smudge and install over 150 red dresses across both campuses ${ }^{5}$.

The project ran from March $5^{\text {th }}$ to $9^{\text {th }}$ and involved an opening ceremony at each of the events, including a women's honour song by our Traditional Knowledge Keeper, Amy Desjarlais (Anishinaabe); a Jingle Dance by York student, Wenzdae Brewster (Métis); and a big drum performance at our final event by the youth drum group, All Nations Juniors. ${ }^{6}$ Our keynote speakers included Glendon's Anishinaabe Linguistics Professor, Maya Ode'amik Chacaby and the REDress Project creator, Jamie Black. The panel discussants were Professor Bonita Lawrence (Mi'kMaw); Professor Ruth Koleszar-Green (Mohawk), who is also special advisor to the president on Indigenous initiatives; Nicole Penak (Mi'kmaq); and Aboriginal Students Association Executive Member, Erin Goulais (Anishinaabe). Last and most importantly, Elder, Joyce Carpenter (Anishinaabe), was our honoured guest. She shared the painful story of the loss of her 14-year-old daughter and the impact this had on her three-month-old grandson, herself and her community, and the retraumatization she experienced at the hands of the police investigating her daughter's murder. Twenty-three years later she continues to speak out at MMIWGT2S events to ensure that her daughter's murder is not forgotten.

\footnotetext{
${ }^{4}$ The REDress Project at York was presented by The Indigenous Students Association of Glendon (ISAG) in partnership with the Office of the President, the Office of the Vice-Provost Academic, the Office of the Vice-Provost Students, Indigenous Council at York, Centre for Aboriginal Students Services (CASS), Aboriginal Students' Association at York (ASAY), Osgood Indigenous Students Association (OISA), Sexual Violence Response Office (SVRO), Center for Human Rights, Equity \& Inclusion, Department of Safety \& Security, Dress for Success in Orillia, Barrie and Toronto, Ontario.

${ }^{5}$ Smudging is a process of creating smoke by burning sacred plants such as sage, sweet grass and cedar. In North America, smudging is a common ceremonial practice among Indigenous peoples. The dresses were smudged with sage with the intention of purifying them. Once smudged, they are considered sacred objects and represent the lives of those who are missing or murdered.

${ }^{6}$ In many Indigenous North American cultures, traditional songs are used to pray, give thanks and socialize. Jingle dancers carry healing visions to their people. To have this responsibility is humbling and an honour, and the drum is central to accompanying songs and carries the heartbeat of Mother Earth calling Indigenous peoples to come together. It is used to rejuvenate and bring balance through singing, dancing and listening to the heartbeat.
} 


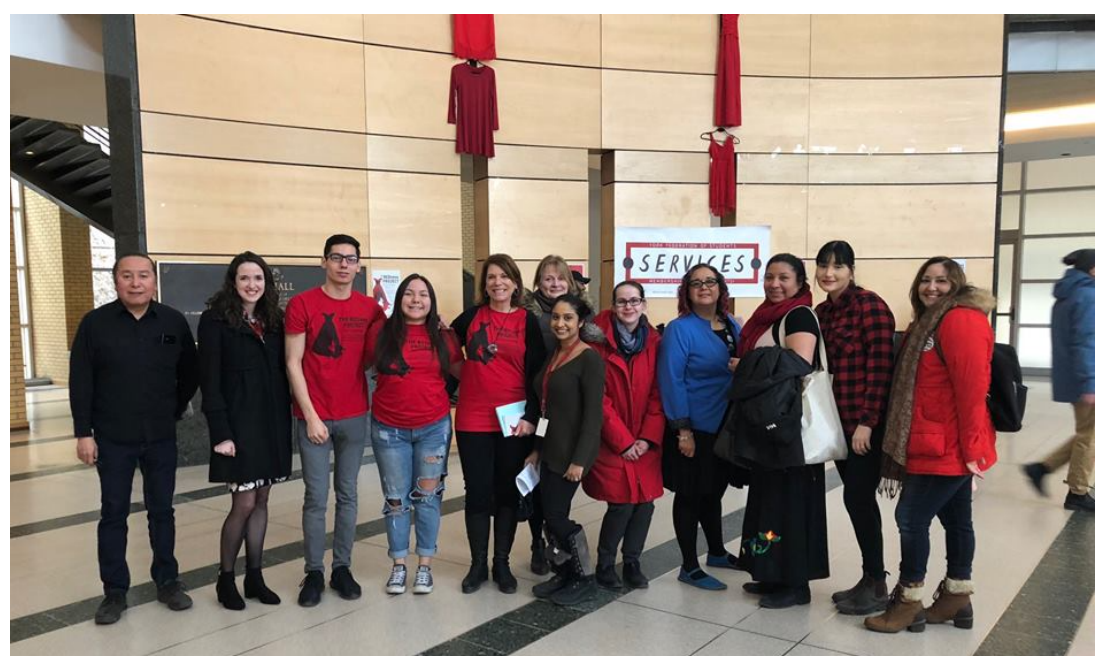

Figure 1. Members of the REDress Project Committee, York University, Vari Hall (Photo by Krisha Ravikantharja).

Both events were very successful, with over 70 participants at the Glendon venue and over 120 participants at the Keele venue. ${ }^{7}$ I believe the main reason for this success is that, from the project's inception, its organization and implementation was oriented toward an Indigenous feminist anti-racist worldview. Cree feminist scholar, Robyn Bourgeois (2017) has proposed an Indigenous feminist anti-oppression framework that resonates well with our group's collective approach in raising awareness to end gender-based violence. Drawing on feminist Indigenous and non-Indigenous scholarship in anti-racism and decolonizing anti-oppression work, she (Bourgeois, 2017, p. 255) asserts that such a framework begins with respecting and honoring Indigenous women and girls' own lived experience and knowledge. She states, "as expert's in their own lives, their leadership and perspectives must be included in any discussion, decision and action with the potential to impact their lives. As the popular political slogan states: 'Nothing about us without us"” (Bourgeois, 2017, p. 255).

Like Kirk, Bourgeois also contends that in order to apply an antioppressive framework, we need to recognize that the systems of oppression that impact Indigenous and other marginalized people are interconnected with racism, patriarchy and colonialism, and work together to maintain and

\footnotetext{
${ }^{7}$ Unfortunately, the installation of the REDress Project and its events began at the outset of the labour dispute between the York University's administration and Canadian Union of Public Employees, CUPE Local 3903, representing contract faculty, teaching assistants and graduate assistants. However, in a show of solidarity with Indigenous peoples and recognition of their presence on Indigenous land, the Local set up a special entrance for REDress participants to access the venue without crossing the picket lines.
} 
perpetuate hierarchical social relations of domination (Bourgeois, 2017; Mundy \& Drydon Peterson 2011). As a result, Bourgeois (2017, p. 270) argues that in order for this framework to be effective, we must also acknowledge the Canadian state's role in the violence it continues to inflict on MMIWGT2S and other oppressed groups, and take steps to address and "dismantle settler colonial domination in Canada." But such efforts cannot be undertaken by Indigenous people alone; working with allies in our efforts to end colonial rule is needed for us to move collectively towards antioppressive and anti-racist social relationships. The importance of this allyship is something that Kirk understood well.

From the outset of the REDress Project, our working group members both honoured and respected the leadership of our student, Kanisha Brown-Bear; the important support from our Indigenous staff at the Center for Aboriginal Student Services (CASS), Randy Pitawanakwat (Anishinaabe) and Nancy Johnson (Anishinaabe); the spiritual leadership and mentorship of our Traditional Knowledge Keeper, Amy Desjarlais; and the mentorship provided by many of us on the Indigenous Council at York (ICY). Honour and respect for all involved was ever present. But our non-Indigenous allies and committee members did more than play supportive roles; they took-up major administrative, communication, accounting and logistical roles, working alongside our Indigenous members in supportive, loving and politically helpful ways. From administering the registration of students attending our ally training sessions and events, to collecting, cleaning and installing dresses across our two campuses, there was no task or request that was too difficult, mundane or problematic for this amazing team.

This collaborative effort provided us with an important opportunity to work together to bring awareness to the York community about MMIWGT2S. The installation of the dresses themselves illustrated the power of art in creating change. Students who saw the empty dresses in the University's public spaces were able to talk with their peers and the Indigenous community about their significance. Throughout the REDress installation and events, student allies were also on hand to pass out information pamphlets that explained the purpose of the installation, answer any questions and invite people to our panel discussions. We also ensured that Indigenous trauma counsellors were available to speak with students, faculty, staff or guests who might experience emotional trauma or distress.

Our keynote speakers created an opportunity to share important information about the Canadian state's involvement in colonization and the need to challenge settler colonialism. As Jamie Black shared in her talk:

The project opens up a space for truth telling for families and for Indigenous women in this country and that is a really important conversation for us to have. These dresses are calling in the spirit of these women who are 'lost' but they are not lost, they are with us all the time, they are with us right now. We put up these dresses, we mark them and we give them a space to fill and they dance. And we 


\section{Elizabeth Brulé}

can't forget them and they can't forget them when we create that space for them to dance. (Black, 2017, 10:58-11:24)

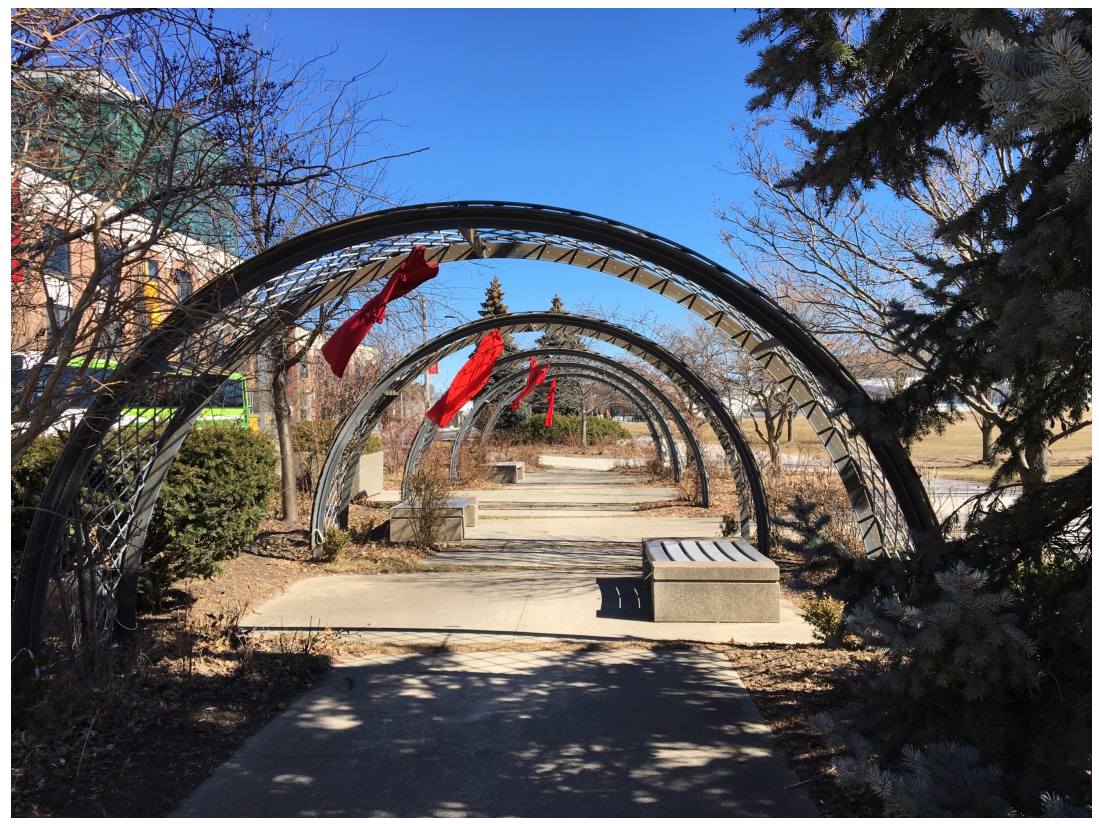

Figure 2. York University, The Commons Walkway (Photo by Elizabeth Brulé, March 4, 2018).

Maya Ode'amik Chacaby also spoke about her lived experience of being a "lost" Indigenous woman, who was not lost because of her own actions or mental state but subjected to ongoing racialized and gendered colonial violence. She wanted to share with us how she came to be missing, "that space between Being Missing and Being Murdered" (Chacaby, 2017, p. 126). Reading from a recent article, she said, "so, I am putting on one of those Red Dresses and dancing a ghost dance about that disposed, missing and forgotten space" (Chacaby, 2017, p. 125). Her presentation, prose and analyses were exceedingly powerful, leaving her audience to reflect on the magnitude of the Canadian state's acts of genocide against Indigenous peoples. Our remaining panel discussants addressed issues of homelessness, community grief and settler relations, all of which have contributed to the structural violence that Indigenous women, girls, transgender and two-spirit persons have had to contend with since colonization. It is this sharing of knowledge - that is,

\footnotetext{
${ }^{8}$ To hear the full recording of Jamie Black's presentation, see https://drive.google.com/file/d/1hvCbv9M_-HKW-KsnV27RPHTEQQRcZT4_/view
} 
spiritual, emotional, intellectual and connected to the land - that provides us with the seeds for change. ${ }^{9}$

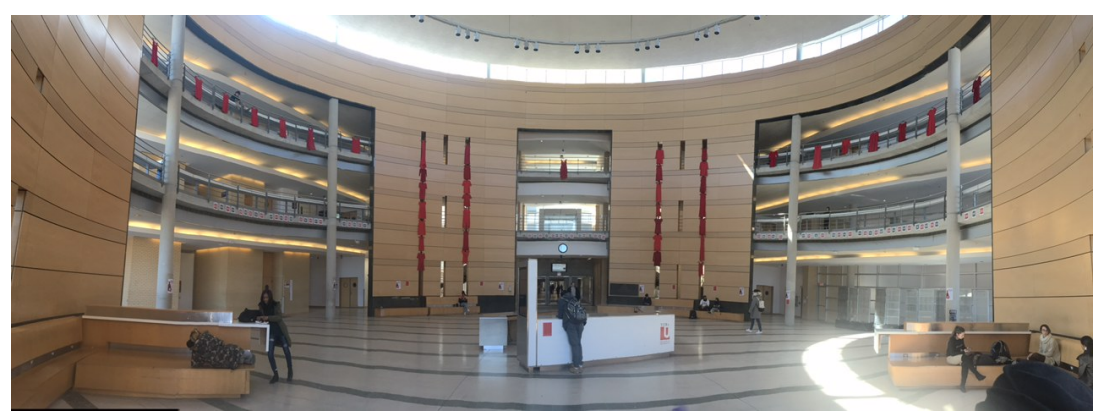

Figure 3. York University, Vari Hall (Photo by Ruth Koleszar-Green, March 4, 2018)

In reflecting on Kirk's work to achieve gender equality through education, and the framework she developed to help us understand the gendered and racialized dynamics of education, I am grateful that her work continues to be celebrated and acknowledged. Her dedication, passion and allyship are reflected in her colleague, Lyndsay Bird's (2010, p. 179), tribute to her: "her warm personality, sense of humor, her willingness to speak the truth to those in power and her belief that the world can become a better place [are] sorely missed." I believe it is through the dedication, passion and allyship from nonIndigenous allies such as Jackie Kirk and Indigenous feminist academics and activists alike that we will bring about the change needed on our path to Indigenous resurgence, reclamation and, ultimately, decolonization.

\section{References}

Bird, L. (2010). A tribute to Jackie: Trainer, researcher and scholar. Girlhood Studies, 3(1), 178179.

Black, J. (2014). The REDress Project. Winnipeg: Jamie Black Word Press. Retrieved from http://www.theredressproject.org

Black, J. (2017). The REDress York University Keynote. Audiovisual recording retrieved from https://drive.google.com/file/d/1hvCbv9M_-HKW-KsnV27RPHTEQQRcZT4_/view

Bourgeois, R. (2017). Perpetual state of violence: An Indigenous feminist anti-oppression inquiry into missing and murdered Indigenous women and girls. In Joyce Green (Ed.), Making space for Indigenous feminism ( $2^{\text {nd }}$ ed.) (pp. 253-273). Halifax, NS: Fernwood Publishing.

Chacaby, M. O. (2017). (The missing chapter) On being missing. In K. Anderson, M. Campbell \& C. Belcourt (Eds.), Keetsahnak: Our missing and murdered Indigenous sisters (pp. 125143). Edmonton, AB: University of Alberta Press.

\footnotetext{
${ }^{9}$ See Simpson (2014) for a Nishnaabeg epistemological understanding of the significance of land-based practices.
} 


\section{Elizabeth Brulé}

Kirk, J. (Ed.). (2009). Certification counts: Recognizing the learning attainments of displaced refugee students. Paris: UNESCO.

Kubik. W., \& Bourassa, C, (2016). Stolen sisters: The politics, policies, and travesty of missing and murdered women in Canada. In E. Memee Lavell-Harvard \& J. Brant (Eds.), Forever loved: Exposing the hidden crisis of missing and murdered Indigenous women and girls in Canada (pp. 17-33). Bradford, ON: Demeter Press.

Bill 132, The Sexual Violence and Harassment Action Plan Act. (2016). Legislative Assembly of Ontario. Toronto: Government of Ontario.

Mango, C., \& Kirk, J. (2008). Imaging girls: Visual methodologies and messages for girls' education. Compare: A Journal of Comparative Education, 38(3), 349-346.

Mango, C., \& Kirk, J. (2010). Sight unseen: Re-viewing images of girls' education. Girlhood Studies, 3(1), 9-33.

Mundy, E., \& Dryden Peterson, S. (Eds.). (2011). Educating children in conflict zones: Research, policy and practice for systemic change - A tribute to Jackie Kirk. New York: Teachers College Press.

NWAC (Native Women's Association of Canada). (2009). Fact sheet: Missing and murdered Aboriginal women and girls. Ottawa: NWAC. Retrieved from www.nwac.ca/wpcontent/uploads/2015/05/Fact_Sheet_Missing_and_Murdered_Aboriginal _Women_and_Girls.pdf

Simpson, L. (2014). Land as pedagogy: Nishnaabeg intelligence and rebellious transformation. Decolonization: Indigeneity, Education \& Society, 3(3), 1-25.

Smith, L. T. (2012). Decolonizing methodologies: Research and Indigenous peoples (2 ${ }^{\text {nd }}$ ed.). London: Zed Books.

Statistics Canada. (2017). Education in Canada: Key results from the 2016 Census. Ottawa: Statistics Canada.

TRC (Truth and Reconciliation Commission of Canada). (2015). The final report of the Truth and Reconciliation Commission recommendations. Toronto: McGill-Queen's University Press. 